\title{
Modeling of solute segregation and the formation of non-metallic inclusions during solidification of a titanium-containing steel
}

\author{
D. Kalisz*, P. L. Żak \\ AGH University of Science and Technology, Faculty of Foundry Engineering, 30 Mickiewicza AV, 30-059 Krakow, Poland
}

Received 18 September 2013, received in revised form 4 June 2014, accepted 3 July 2014

\begin{abstract}
Solute segregation and formation of non-metallic inclusions during the solidification of a titanium-containing steel are modeled in this paper. The Ueshima model was used to describe the partitioning of solute elements in the steel, taking account of back-diffusion into the solid. Calculations were made for solidification of an AH-36-3u steel ingot cooled at 50 or 100 $\mathrm{K} \mathrm{min}^{-1}$. The simulations reveal that $\mathrm{MnS}$ inclusions are formed first, followed by $\mathrm{TiN}, \mathrm{Ti}_{2} \mathrm{O}_{3}$ and $\mathrm{SiO}_{2}$. Increased cooling rate accelerates the formation of non-metallic inclusions, but for the assumed rates of 50 and $100 \mathrm{~K} \mathrm{~min}^{-1}$ the differences in amount formed are minimal. The results of these calculations for $\mathrm{AH}-36-3 \mathrm{u}$ steel give an approximate picture of the distribution of inclusions in the solidified ingot structure.
\end{abstract}

K e y w o r d s: segregation, ingot solidification, non-metallic inclusions, back-diffusion

\section{Introduction}

During the solidification of a steel, in principle all the elemental components segregate preferentially to the solid or to the liquid phase. The actual composition of the liquid phase sets the thermodynamic criterion for the formation of compound particles (i.e. non-metallic inclusions). From solute elements $A$ and $\mathrm{B}$, the compound $\mathrm{A}_{a} \mathrm{~B}_{b}$ can form according to:

$$
a \mathrm{~A}+b \mathrm{~B}=\mathrm{A}_{a} \mathrm{~B}_{b},
$$

with an associated Gibbs free-energy change $\left(\mathrm{J} \mathrm{mol}^{-1}\right)$ given by:

$$
\Delta G=-R T \ln K,
$$

where $R$ is the gas constant $\left(\mathrm{J} \mathrm{mol}^{-1} \mathrm{~K}^{-1}\right), T$ is the temperature $(\mathrm{K})$ and $K$ is the equilibrium constant for the reaction. The reaction is favorable, i.e. inclusions are formed, if $\Delta G<0$. For the solutes under consideration, the liquidus and solidus curves on the iron-rich side of the relevant phase diagrams show that the solutes are partitioned into the liquid phase, successively increasing the solute content in the liquid as solidification proceeds. The highest solute content is observed in the last portion of liquid. The enrichment of solute content and continuing cooling favor the formation of oxides, sulfides and nitrides.

When analyzing the solidification of an alloy, e.g. a steel, two extreme cases can be distinguished:

(i) equilibrium solidification, when the diffusion in the solid phase is fast enough to immediately compensate for concentration differences in this phase. With this assumption, the concentration $C_{\mathrm{S}}^{*}$ of a given solute in the solid is uniform at the level of the equilibrium concentration in the solid at its interface with the liquid. This concentration is given by [1]:

$$
C_{\mathrm{S}}^{*}=\frac{k C_{0}}{1+f_{\mathrm{S}}(k-1)},
$$

where $C_{0}$ is the initial concentration of the given solute in the liquid, $f_{\mathrm{S}}$ is the mass fraction of the solid, and $k$ is the equilibrium partition coefficient.

(ii) non-equilibrium solidification, in the lack of diffusion in solid state, described by the Scheil equation [1]:

$$
C_{\mathrm{S}}^{*}=k C_{0}\left(1-f_{\mathrm{S}}\right)^{k-1} .
$$

*Corresponding author: tel./fax: + 48 532437147; e-mail address: dak@agh.edu.pl 
At the solidification front, as a portion of liquid transforms to solid, the content of a solute within the crystallizing portion is divided into two parts. One part is partitioned into the remaining liquid, enriching its solute content; the other part is incorporated into the solid, and spreads into the bulk by so-called back diffusion. The back-diffusion lowers the equilibrium concentration of the given solute in the liquid phase. The parameter $\alpha_{i}$ characterizing the share of back-diffusion for the solute " $i$ " in the liquid is given by $[1]$ :

$$
\alpha_{i}=\frac{D_{\mathrm{s}, i} t_{\mathrm{s}}}{l^{2}}
$$

where $D_{\mathrm{s}, i}$ is the diffusion coefficient $\left(\mathrm{m}^{2} \mathrm{~s}^{-1}\right)$ of solute $i$ in the solid phase, $l$ is the incremental advance $(\mathrm{m})$ of the solidification front, and $t_{\mathrm{s}}$ is the local solidification time (i.e., the time needed for total solidification of a given part of the liquid), given by:

$$
t_{\mathrm{s}}=\frac{T_{\mathrm{L}}-T_{\mathrm{S}}}{P},
$$

where $T_{\mathrm{L}}$ is the liquidus temperature for the initial steel composition, $T_{\mathrm{S}}$ is the solidus temperature for the last portion of liquid steel in the analyzed volume, and $P$ is the cooling rate $\left(\mathrm{K} \mathrm{s}^{-1}\right)$. Several equations have been proposed for the description of solidification with back-diffusion:

(i) the Brody \& Flemings equation [2] for a parabolic increase in solid phase in dendritic crystallization:

$$
C_{\mathrm{S}}^{*}=k C_{0}\left[1-(1-2 \alpha k) f_{\mathrm{S}}\right]^{\frac{k-1}{1-2 \alpha k}},
$$

where

$$
\alpha=\frac{4 t_{\mathrm{s}} D_{\mathrm{s}, i}}{\lambda^{2}},
$$

and $\lambda$ is the secondary dendrite arm spacing (m);

(ii) the Wołczyński equation [1]:

$$
C_{\mathrm{S}}^{*}=k C_{0}\left[1+\alpha k f_{\mathrm{S}}-f_{\mathrm{S}}\right]^{\frac{k-1}{1-2 \alpha k}}
$$

(iii) the Clyne \& Kurz equation [3]:

$$
C_{\mathrm{S}}^{*}=k C_{0}\left[(1-2 \Omega k) f_{\mathrm{S}}\right]^{\frac{(k-1)}{(1-2 \Omega k)}}
$$

where

$$
\Omega=\alpha\left[1-\exp \left(-\frac{1}{\alpha}\right)\right]-0.5 \exp \left(-\frac{1}{2 \alpha}\right) ;
$$

(iv) the Ohnaka equation [4]:

$$
C_{\mathrm{S}}^{*}=k C_{0}\left[1-(1-\beta k) f_{\mathrm{S}}\right]^{\frac{k-1}{1-\beta k}},
$$

Table 1. Diffusion coefficients in the solid phase (ferrite) and the equilibrium partition coefficients $k^{\delta / L}$ for selected solutes in the AH-36-3u steel $[6,7]$

\begin{tabular}{lcl}
\hline & $D_{\sigma} \times 10^{-4}\left(\mathrm{~m}^{2} \mathrm{~s}^{-1}\right)$ & \\
\cline { 2 - 2 } Element & $k^{\delta / L}$ & \\
\hline $\mathrm{Mn}$ & $0.76 \exp (-223472 / R T)$ & 0.77 \\
$\mathrm{~S}$ & $4.56 \exp (-214443 / R T)$ & 0.05 \\
$\mathrm{Si}$ & $8 \exp (-248710 / R T)$ & 0.77 \\
$\mathrm{C}$ & $0.0127 \exp (-81301 / R T)$ & 0.19 \\
$\mathrm{P}$ & $2.9 \exp (-229900 / R T)$ & 0.23 \\
$\mathrm{Al}$ & $5.9 \exp (-241186 / R T)$ & 0.6 \\
$\mathrm{O}$ & $0.0371 \exp (-96349 / R T)$ & 0.03 \\
$\mathrm{~N}$ & $10^{-2405 / T-2.97}$ & 0.32 \\
$\mathrm{Ti}$ & $3.15 \exp (-247693 / R T)$ & 0.38 \\
\hline
\end{tabular}

where the back-diffusion parameter $\beta$ is given by

$$
\beta=\frac{2 \gamma}{(1+2 \gamma)}=\frac{4 \alpha}{(1+4 \alpha)},
$$

and

$$
\gamma=\frac{8 t_{\mathrm{s}} D_{\mathrm{s}, i}}{\lambda^{2}}=2 \alpha
$$

(v) the Kobayashi equation [5]:

$$
\begin{aligned}
& C_{\mathrm{S}}^{*}=k C_{0} \xi^{\frac{(k-1)}{(1-\beta k)}}\{1+ \\
& \left.+\Gamma\left[0.5\left(\xi^{-2}-1\right)-2\left(\xi^{-1}-1\right)-\ln \xi\right]\right\},
\end{aligned}
$$

where

$$
\xi=1-(1-\beta k) f_{\mathrm{S}},
$$

and

$$
\Gamma=\beta^{3} k(k-1)[(1+\beta) K-2](4 \gamma)^{-1}(1-\beta k)^{-3} .
$$

The temperature-dependent diffusion coefficients and the equilibrium partition coefficients are listed in Table 1.

The solidus temperature $T_{\mathrm{S}}$ cannot be pre-calculated as it depends on the changing liquid composition, which in turn depends on the degree of solute segregation as affected by back-diffusion and on the mass of the inclusions that are formed. The back-diffusion parameter $\alpha$ is a function of local solidification time $t_{\mathrm{s}}$, which directly depends on the temperature difference between the beginning and end of the solidification process. Hence, an iterative method has to be used for determining the temperature at the end of solidification. 


\section{Analysis of solute effects on the steel solidification}

The behavior of solute elements in liquid steel during solidification is described by, e.g., the mathematical model due to Ueshima et al. [6, 8, 9]. In this model, the solid phase can be separated from liquid during dendritic crystallization taking place in the condition of directional cooling. If the analysis focuses only on $\delta$-phase crystallization, then all the solutes tend to partition into the liquid. Under such conditions, inclusions are formed in the liquid as solidification proceeds. The concentration $C_{i 0}$ of solute $\mathrm{i}$ in the first solidified portion is given by:

$$
C_{i 0}=C_{i \mathrm{~L}}^{0} k_{i}^{\delta / \mathrm{L}},
$$

where $C_{i \mathrm{~L}}^{0}$ is the initial concentration of the solute in the liquid, and $k_{i}^{\delta / \mathrm{L}}$ is the solid/liquid partition coefficient for the solute.

As solidification proceeds, the liquid is enriched with solute $i$, and consequently successive portions of the growing solid also incorporate increasing amounts of the solute. The Ueshima model analyzes solidification of a selected layer perpendicular to the dendrite arm axis. During solidification the layer does not exchange mass with the environment, and its temperature decreases from the liquidus $T_{\mathrm{L}}$ to the solidus $T_{\mathrm{S}}$. The time needed for solidification of a layer, i.e. the local solidification time $t_{\mathrm{s}}$, depends on the cooling rate $P$ :

$$
P=\frac{T_{\mathrm{L}}-T_{\mathrm{S}}}{t_{\mathrm{S}}}
$$

The layer solidifies from the dendrite axis outwards towards its edge. The solidification front is almost flat. A simple description of the diffusion in the solid is adopted, substituting 1-D diffusion in the layer for 3-D diffusion in the bulk. The calculation domain is divided into $N$ cells. At a given point in time $(t-\Delta t)$ it is assumed that temperature is uniform within each cell. Of the $N$ cells: $m$ are taken to be solid (cells numbered 1 to $m$ ) phase, and the rest (cells $(m+1)$ to $N$ ) represent the liquid. If by the next point in time, $t$, the temperature drops enough, then the interface is shifted by one cell. The diffusion in the liquid is fast enough to make the concentration of a solute uniform throughout the phase at any time. The diffusion of solute $i$ in the solid phase is described using Fick's second law:

$$
\frac{\partial C_{i}}{\partial t}=D_{\mathrm{s}, i} \frac{\partial^{2} C_{i}}{\partial x^{2}}
$$

where $C_{i}$ is the concentration of solute $i$ in the solid.

After introducing finite differences in the place of differentials, the following expressions are obtained:
1. For a cell at the dendrite axis $(n=1)$ :

$$
\frac{C_{i 1}^{t}-C_{i 1}^{t-\Delta t}}{\Delta t}=D_{\mathrm{s}, i} \frac{C_{i 2}^{t-\Delta t}-C_{i 1}^{t-\Delta t}}{(\Delta x)^{2}}
$$

2. For a cell in the solid phase $(1<n<m)$ :

$$
\begin{aligned}
& \frac{C_{i n}^{t}-C_{i n}^{t-\Delta t}}{\Delta t}= \\
& D_{\mathrm{s}, i} \frac{\left(C_{i(n+1)}^{t-\Delta t}-C_{i n}^{t-\Delta t}\right)-\left(C_{i n}^{t-\Delta t}-C_{i(n-1)}^{t-\Delta t}\right)}{(\Delta x)^{2}} .
\end{aligned}
$$

3. For a cell on the interface $(n=m)$ at any point of time:

$$
C_{i m}^{t}=C_{i \mathrm{~L}}^{t} k_{i}^{\delta / \mathrm{L}}
$$

4. For every cell in the liquid $(m<n<N)$ the concentration is equal to $C_{i \mathrm{~L}}^{t}$. At each time step in the computation, the following balance equation is satisfied for each solute:

$$
N C_{i \mathrm{~L}}^{0}=\sum_{n}^{m} C_{i n}^{t}+(N-m) C_{i \mathrm{~L}}^{t}
$$

Equations (26) and (27) enable one to calculate the concentration of solute $i$ at the time $t$ both in the liquid phase $\left(C_{i \mathrm{~L}}^{t}\right)$, and in a solidifying cell $m\left(C_{i m}^{t}\right)$ :

$$
\begin{gathered}
C_{i \mathrm{~L}}^{t}=\frac{N C_{i \mathrm{~L}}^{t}-\sum_{n=1}^{m-1} C_{i \mathrm{n}}^{t-\Delta t}-f C_{i(m-1)}^{t-\Delta t}}{(N-m)+(1-F) k_{i}^{\delta / \mathrm{L}}}, \\
C_{i m}^{t}=\frac{C_{i \mathrm{~L}}^{t}}{k_{i}^{\delta / \mathrm{L}}}
\end{gathered}
$$

The parameter $F$ is determined by the given solidification conditions, i.e. the width of the cell, the assumed time step $\Delta t$, the local solidification time $t_{\mathrm{s}}$ resulting from the difference of liquidus and solidus temperatures and the cooling rate $P$ :

$$
F=D \frac{\Delta t}{\Delta x^{2}}=\frac{4 D t_{\mathrm{s}}}{L^{2}} N^{2}\left[\left(f_{\mathrm{S}}^{t}\right)^{2}-\left(f_{\mathrm{S}}^{t-\Delta t}\right)^{2}\right]
$$

where $f_{\mathrm{S}}^{t}$ is the fraction of solid phase at time $t$.

It is assumed that the solidification rate scales parabolically with the solidification time. For a given chemical composition of the steel, the liquidus $T_{\mathrm{L}}$ and solidus $T_{\mathrm{S}}$ temperatures can be computed from known formulas $[32,33]$. Based on the solid fraction $f_{s}$, one 
Table 2. Chemical composition of AH-36-3u steel assumed for the calculations of solute segregation and inclusion formation (wt.\%)

\begin{tabular}{lcccccccc}
\hline Type of steel & $\mathrm{C}$ & $\mathrm{Mn}$ & $\mathrm{Si}$ & $\mathrm{P}$ & $\mathrm{S}$ & $\mathrm{Ti}$ & $\mathrm{O}$ & $\mathrm{N}$ \\
\hline AH-36-3u & 0.18 & 1.60 & 0.25 & 0.025 & 0.012 & 0.02 & 0.0005 & 0.005 \\
\hline
\end{tabular}

Table 3. First-order reaction parameters [12, 13]

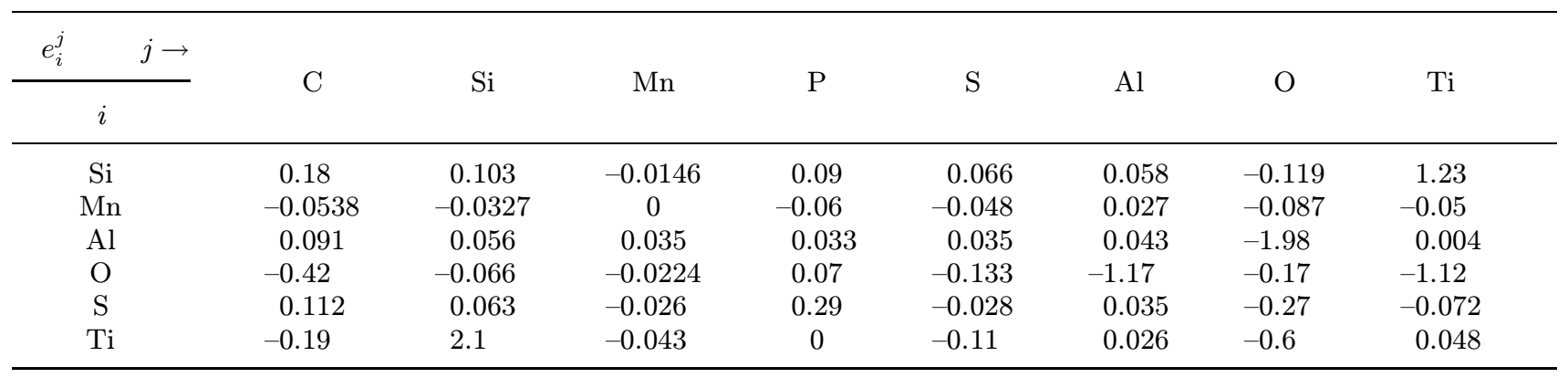

Table 4. Reaction parameters after Banya $[14,15]$

\begin{tabular}{|c|c|c|c|c|}
\hline & $\mathrm{MnO}$ & $\mathrm{SiO}_{2}$ & $\mathrm{TiO}_{2}$ & $\mathrm{AlO}_{1.5}$ \\
\hline $\begin{array}{l}\mathrm{MnO} \\
\mathrm{SiO}_{2} \\
\mathrm{TiO}_{2}\end{array}$ & & -75310 & $\begin{array}{r}-55000 \\
+15000\end{array}$ & $\begin{array}{r}-83680 \\
-87000 \\
+4000\end{array}$ \\
\hline
\end{tabular}

can calculate the temperature, and so the definite location of cell $n=m$ [10]. The formulation has form:

$$
T=T_{0}-\frac{T_{0}-T_{\mathrm{L}}}{1-f_{\mathrm{S}} \frac{T_{\mathrm{L}}-T_{\mathrm{S}}}{T_{0}-T_{\mathrm{S}}}},
$$

where $T_{0}$ is the melting temperature of pure iron.

Ueshima's analysis addresses dendritic solidification. The distance between dendrite arm axes, denoted as $2 L$, is a function of the cooling rate. The microsegregation model permits calculation of the concentration of each solute in the liquid phase at a given stage of solidification. The inclusions may be formed at an early stage when:

$$
\left(C_{\mathrm{L}(\mathrm{A})}^{t}\right)^{a} f_{\mathrm{A}}^{a}\left(C_{\mathrm{L}(\mathrm{B})}^{t}\right)^{b} f_{\mathrm{B}}^{b} \geq Q_{\mathrm{L}(\mathrm{A} a \mathrm{~B} b)},
$$

where $Q_{\mathrm{L}(\mathrm{A} a \mathrm{~B} b)}$ is a solubility product, $f_{\mathrm{A}}, f_{\mathrm{B}}$ are the activity coefficients of solutes $\mathrm{A}$ and $\mathrm{B}$, and $C_{\mathrm{L}(\mathrm{A})}^{t}$, $C_{\mathrm{L}(\mathrm{B})}^{t}$ are the solute concentrations. The mass balance for a given solute, taking account of inclusion formation, can be expressed as [7]:

$$
\sum_{n=1}^{N} C_{i \mathrm{~L}}^{0}=\sum_{n=1}^{m} C_{i n}^{t}+(N-m) C_{i \mathrm{~L}}^{t} \sum_{n=1}^{m} C_{i n}^{t}(N-n+1),
$$

where $C_{i n}^{t}$ denotes consumption of solute.

\section{Calculation of solute segregation and inclusion formation in the solidifying steel ingot}

Calculations of segregation and inclusion formation were made for AH-36-3u steel, the chemical composition of which is presented in Table 2 .

The liquidus and solidus temperatures were determined from the following expressions [11]:

$$
\begin{aligned}
T_{\mathrm{L}} & =1809-\left\{100.3[\% \mathrm{C}]-22.4[\% \mathrm{C}]^{2}-0.16+\right. \\
& +13.55[\% \mathrm{Si}]-0.64[\mathrm{Si}]^{2}+5.82[\% \mathrm{Mn}]+ \\
& \left.+0.3[\% \mathrm{Mn}]^{2}+4.2[\% \mathrm{Cu}]\right\}, \\
& \\
T_{\mathrm{S}}= & 1809-\{415.5[\% \mathrm{C}]+12.3[\% \mathrm{Si}]+6.8[\% \mathrm{Mn}]+ \\
+ & 124.5[\% \mathrm{P}]+183.9[\% \mathrm{~S}]+4.1[\% \mathrm{Al}]\} .
\end{aligned}
$$

The Ueshima model is used for the calculations. The parameter $L$ in Eq. (28) is taken to be $110 \mathrm{~mm}$. Solidification with back-diffusion is described with dependence (28). The activities of the solutes are calculated using relation (20). The activity of particular solutes was established from the Wagner-Chipman equation. The first-order reaction parameters used in the calculations are given in Table 3 .

The activity of oxide-forming solutes was determined using expressions for a regular-solution model. The reaction parameters given in Table 4 were taken into account in the calculations.

Calculations were performed for equilibrium between the metallic phases and the non-metallic inclusions. The equilibrium constants for formation of the inclusion phases are given in Table 5 . 
Ta ble 5. Equilibrium constants for formation of inclusions in liquid steel $[7,12,16,17]$

\begin{tabular}{clc}
\hline Reaction & Reaction equilibrium constant & Reference \\
\hline $\mathrm{Mn}+\mathrm{S}=\mathrm{MnS}(\mathrm{s})$ & $\log K=8627 / T-4.745$ & {$[12]$} \\
$\mathrm{Si}+2 \mathrm{O}=\mathrm{SiO}_{2}(\mathrm{~s})$ & $\log K=30110 / T-11.40$ & {$[16]$} \\
$2 \mathrm{Ti}+3 \mathrm{O}=\mathrm{Ti}_{2} \mathrm{O}_{3}(\mathrm{~s})$ & $\log K=56060 / T-18.08$ & {$[7]$} \\
$\mathrm{Ti}+\mathrm{N}=\mathrm{TiN}^{(\mathrm{s})}$ & $\log K=19790 / T-7.78$ & {$[17]$} \\
\hline
\end{tabular}
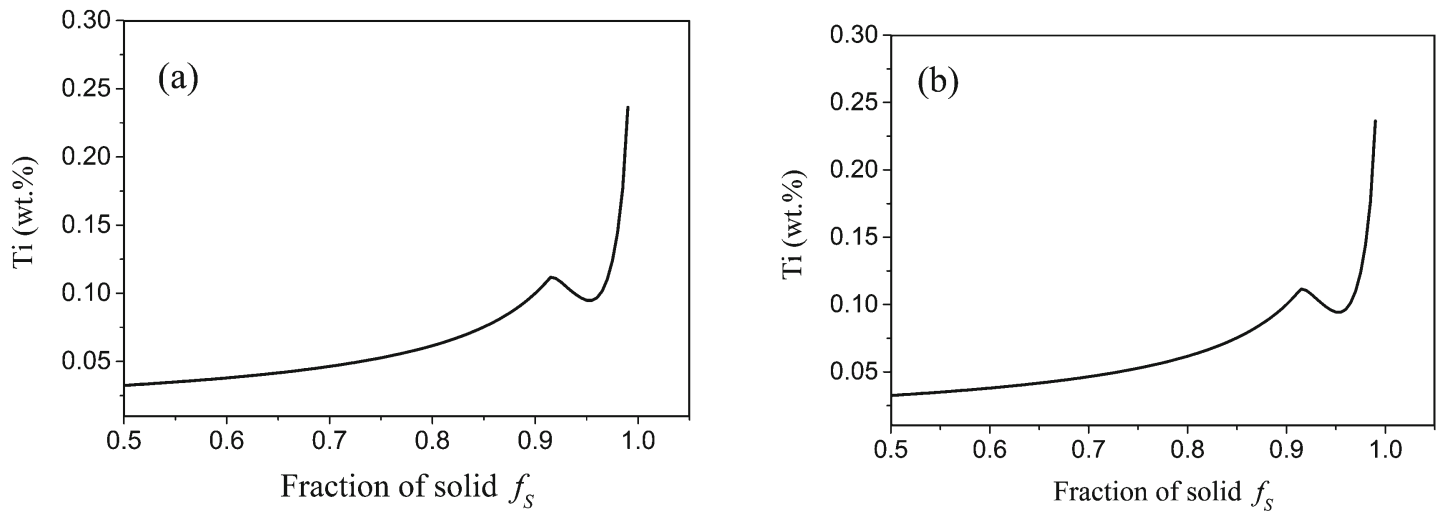

Fig. 1. Titanium segregation during solidification of an AH-36-3u steel ingot at a cooling rate of (a) $50 \mathrm{~K} \mathrm{~min}{ }^{-1}$ and (b) $100 \mathrm{~K} \mathrm{~min}^{-1}$.
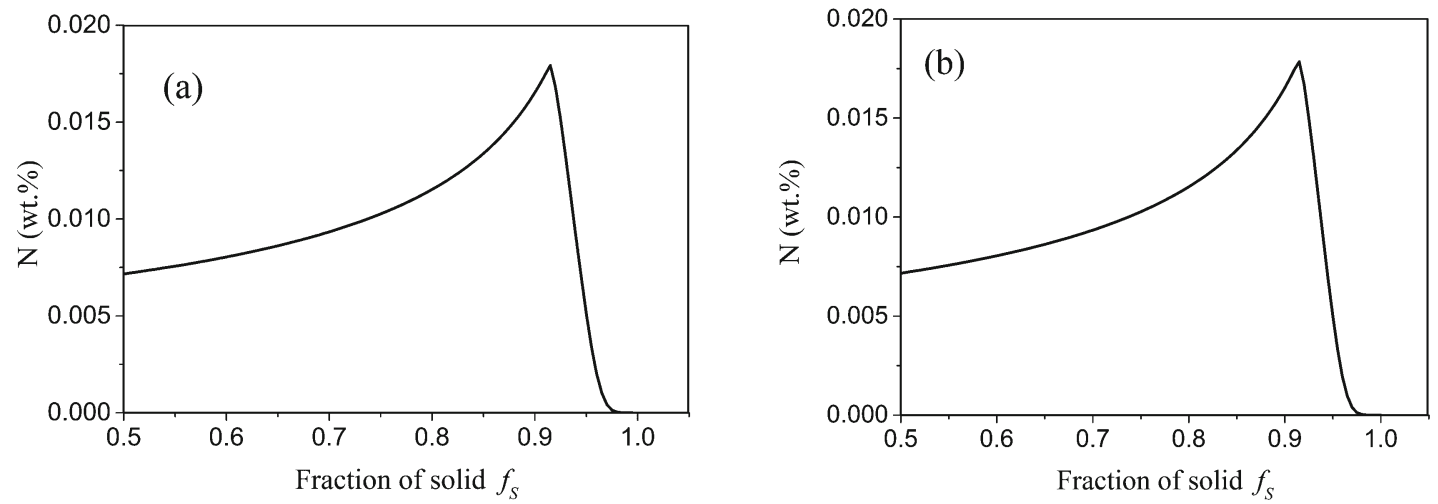

Fig. 2. Nitrogen segregation during solidification of an AH-36-3u steel ingot at a cooling rate of (a) $50 \mathrm{~K} \mathrm{~min}^{-1}$ and (b) $100 \mathrm{~K} \mathrm{~min}^{-1}$.
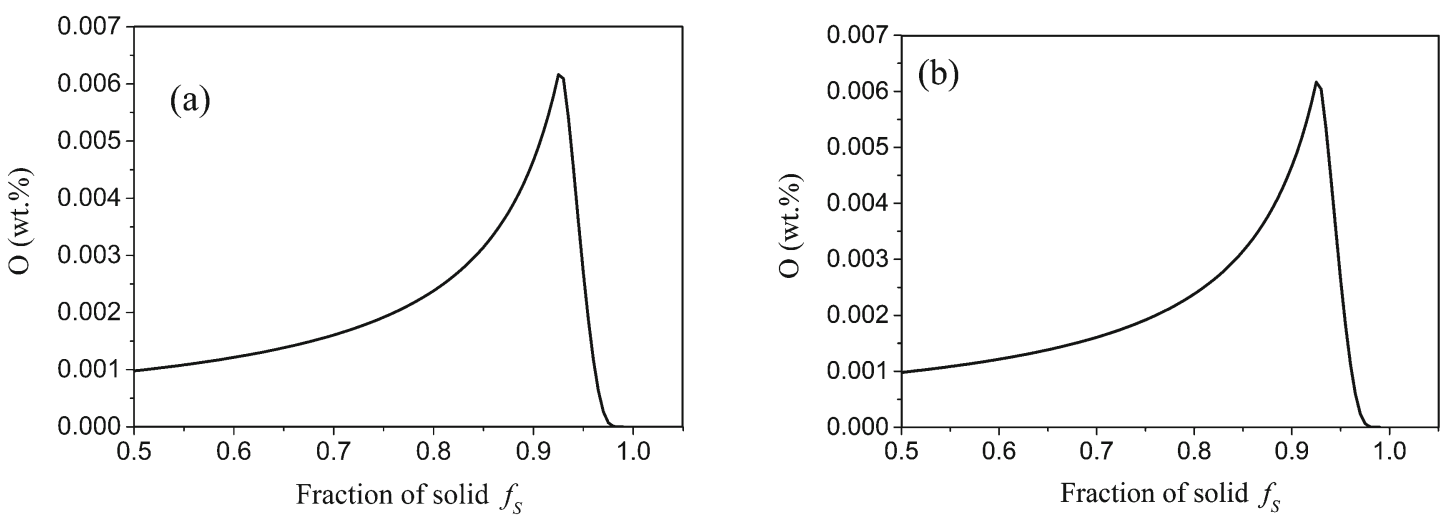

Fig. 3. Oxygen segregation during solidification of an AH-36-3u steel ingot at a cooling rate of (a) $50 \mathrm{~K} \mathrm{~min}^{-1}$ and (b) $100 \mathrm{~K} \mathrm{~min}^{-1}$. 

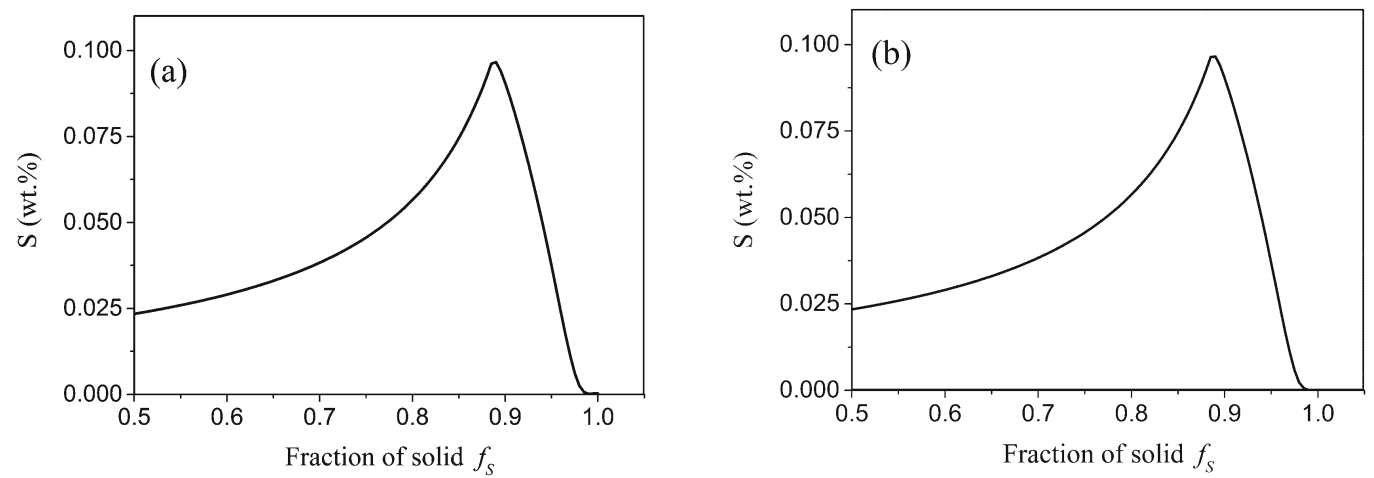

Fig. 4. Sulfur segregation during solidification of an AH-36-3u steel ingot at a cooling rate of (a) $50 \mathrm{~K} \mathrm{~min}^{-1}$ and (b) $100 \mathrm{~K} \mathrm{~min}^{-1}$.
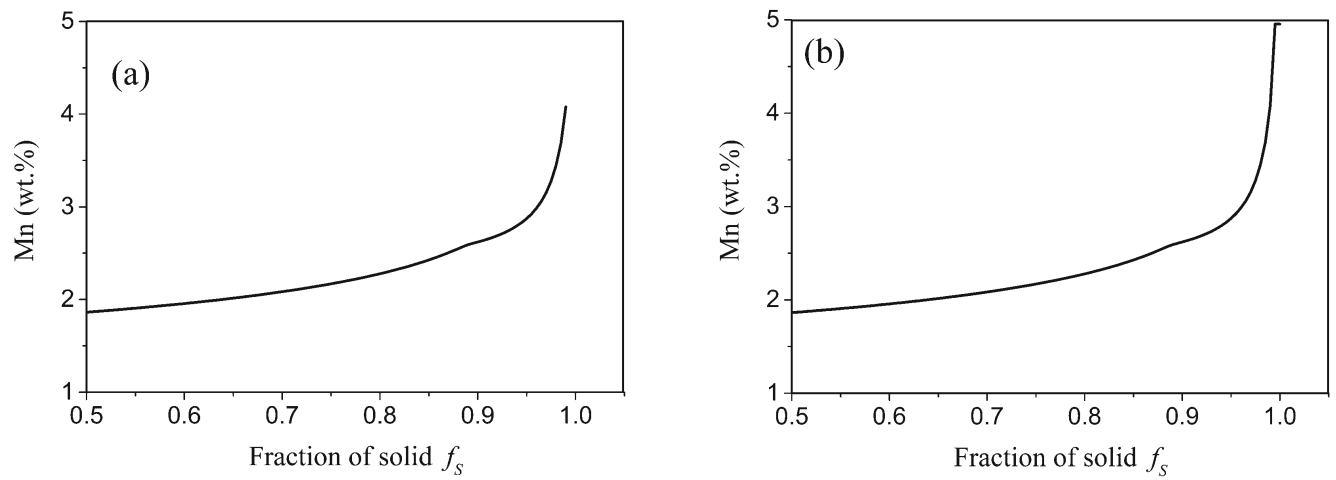

Fig. 5. Manganese segregation during solidification of an AH-36-3u steel ingot at a cooling rate of (a) $50 \mathrm{~K} \mathrm{~min}^{-1}$ and (b) $100 \mathrm{~K} \mathrm{~min}^{-1}$
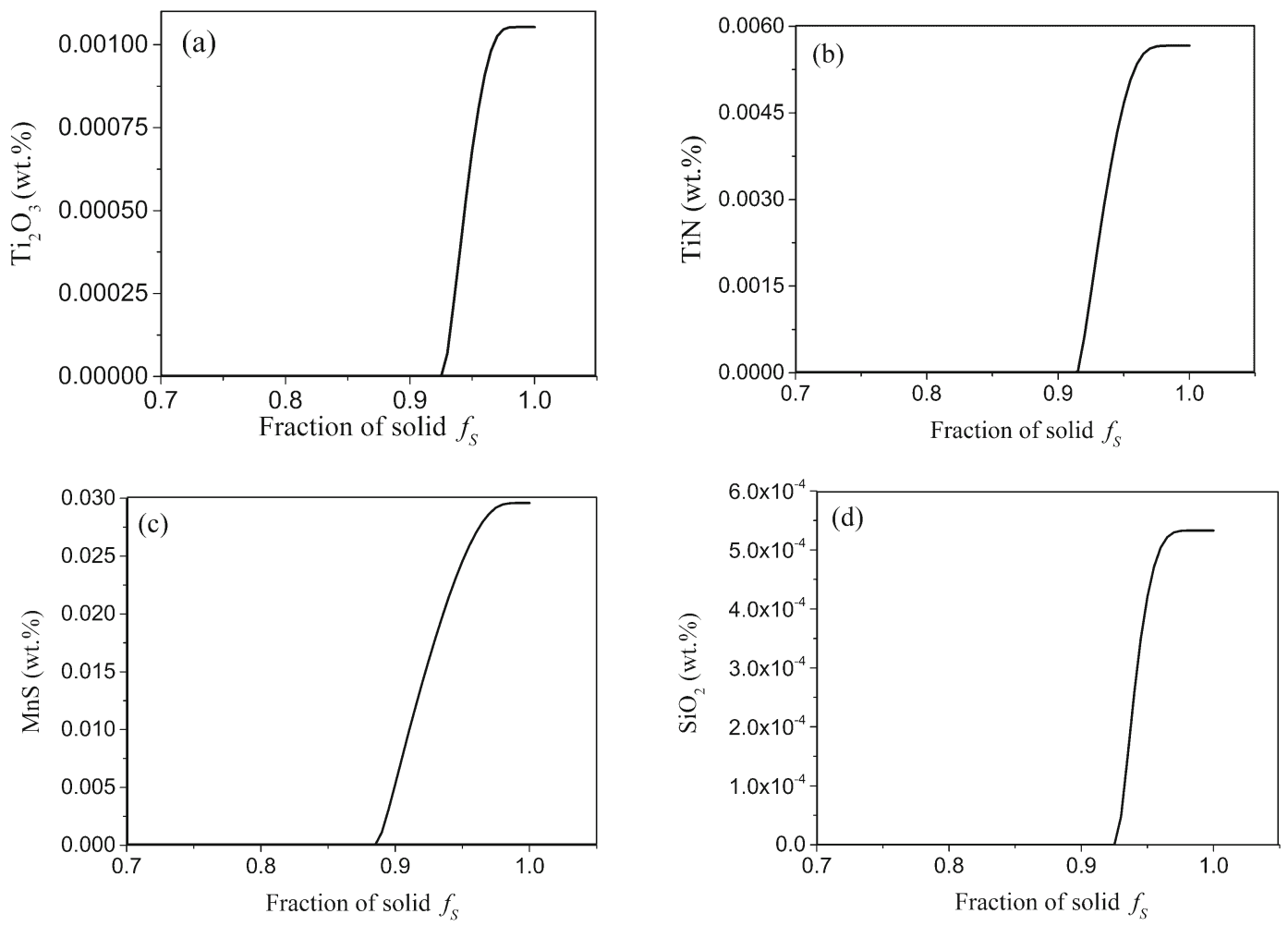

Fig. 6. Formation of non-metallic inclusion phases during solidification of an AH-36-3u steel ingot at a cooling rate of $50 \mathrm{Kmin}^{-1}$. 
It is assumed that the manganese sulfide, titanium nitride and oxide inclusions constitute separate phases with activity equal to 1 . The simplex method was used for the modeling.

Figures 1 to 6 illustrate the change of concentration of particular solutes, and the gradual formation of inclusions in AH-36-3u steel as it solidifies at a cooling rate of $50 \mathrm{~K} \mathrm{~min}^{-1}$. As a result of segregation, the manganese concentration in the liquid phase almost doubles from its initial value of $1.6 \%$, whereas the aluminum content in liquid phase increases three times. The formation of $\mathrm{MnS}, \mathrm{Ti}_{2} \mathrm{O}_{3}$, TiN, and $\mathrm{SiO}_{2}$ is accompanied by a rapid drop of oxygen, sulfur and nitrogen concentrations. The calculations reveal that the concentration of solutes controls the formation of inclusions. The amount of inclusion phase is limited by the content of the solute that is depleted first; in the present case the limiting solutes are oxygen, sulfur and nitrogen. The first formation of inclusions occurs earlier on faster cooling; the comparison of the results for both cooling rates shows that the differences are, however, minimal.

\section{Concluding remarks}

The calculations of solute segregation and of the formation of non-metallic inclusions were performed for the solidification of the titanium-containing steel $\mathrm{AH}-36-3 \mathrm{u}$ at cooling rates of 50 and $100 \mathrm{~K} \mathrm{~min}^{-1}$. These simulations reveal that $\mathrm{MnS}$ particles are formed first, followed by $\mathrm{TiN}, \mathrm{Ti}_{2} \mathrm{O}_{3}$ and $\mathrm{SiO}_{2}$. The silicon content in steel exceeds the titanium content by a factor of 12 , which favors $\mathrm{SiO}_{2}$ formation in the last portions of the solidifying steel. These results on the solidification of AH-36-3u steel ingots give an approximate picture of the distribution of inclusions in the ingot structure. In reality, their distribution is conditioned by the fact that the non-metallic inclusions may interact with the solidification front, may be absorbed by it, or they can accumulate in the ingot center, depending on their location and size. However, the inclusions may also flow out and be assimilated by crystallizer slag, which eventually decides about the distribution of inclusions in particular parts of the cast ingot.

\section{References}

[1] Wołczyński, W.: Effect of the Back - Diffusion onto Doublet Structure Formation and Solute Redistribution Within Alloys Solidiying Directionally, With or Without Convection. Kraków, Polish Academy of Sciences, Institute of Metallurgy and Materials Science 2002.
[2] Brody, H. D., Flemings, M. C.: Trans. Met. Soc. AIME, 236, 1966, p. 615.

[3] Clyne, T. W., Kurz, W.: Met. Trans. A, 12, 1981, p. 965. doi:10.1007/BF02643477

[4] Ohnaka, I.: ISIJ Intern., 26, 1986, p. 1045. doi:10.2355/isijinternational1966.26.1045

[5] Kobayashi, S., Nagamichi, T., Gunji, K.: ISIJ Int., 28, 1988 , p. 543. doi:10.2355/isijinternational1966.28.543

[6] Liu, Z., Wei, J., Cai, K.: ISIJ Int., 42, 2002, p. 958. doi:10.2355/isijinternational.42.958

[7] Ma, Z., Janke, D.: ISIJ Int., 38, 1998, p. 46. doi:10.2355/isijinternational.38.46

[8] Matsumiya, T., Kajioka, H., Mizoguchi, S., Ueshima, Y., Esaka, H.: ISIJ Int., 24, 1984, p. 873. doi:10.2355/isijinternational1966.24.873

[9] Ueshima, Y., Mizoguchi, S., Matsumiya, T., Karioka, H.: Met. Trans. B, 17, 1986, p. 845. doi:10.1007/BF02657148

[10] Goto, H., Miyazawa, K., Yamada, W., Tanaka, K.: ISIJ Int., 35, 1995, p. 708. doi:10.2355/isijinternational.35.708

[11] Suzuki, M., Yamaguchi, R., Murakami, K., Nakada, M.: ISIJ Int., 41, 2001, p. 247. doi:10.2355/isijinternational.41.247

[12] Liu, Z., Gu, K., Cai, K.: ISIJ Int., 42, 2002, p. 950. doi:10.2355/isijinternational.42.950

[13] Manohar, P. A., Dunne, D. P., Chandra, T., Killmore, C. R.: ISIJ Int., 36, 1996, p. 194. doi:10.2355/isijinternational.36.194

[14] Ban-ya, S.: ISIJ Int., 33, 1993, p. 2. doi:10.2355/isijinternational.33.2

[15] Iwanciw, J.: Arch. Met. And Materials, 49, 2004, p. 595.

[16] Suzuki, M., Yamaguchi, R., Murakami, K., Nakada, M.: ISIJ Int., 41, 2001, p. 247. doi:10.2355/isijinternational.41.247

[17] Morita, Z., Tanaka, T., Yanai, T.: Met. Trans. B, 18, 1987, p. 195. doi:10.1007/BF02658444

[18] Kalisz, D.: Thermodynamic Characteristic Formation of Non-Metallic Phase in Liquid Steel. Krakow, Akapit 2013.

[19] Kalisz, D., Rzadkosz, S.: Archives of Foundry Engineering, 13, 2013, p. 63. doi:10.2478/afe-2013-0012

[20] Lelito, J., Zak, P. L., Skirzadi, A. A., Greer, A. L., Krajewski, W. K., Suchy, J. S., Haberl K., Schumacher, P.: Acta Mater., 60, 2012, p. 2950. doi:10.1016/j.actamat.2012.01.058

[21] Longauerowa, M.: Kovove Mater., 36, 1998, p. 348.

[22] Dobrovska, V., Dobrovska, J., Rek, J., Stransky, K.: Kovove Mater., 33, 1995, p. 462.

[23] Lelito, J., Zak, P. L., Greer, A. L., Suchy, J. S., Krajewski, W. K., Gracz, B., Szucki, M., Shirzadi, A. A.: Composites: Part B, 43, 2012, p. 3306. doi:10.1016/j.compositesb.2012.01.088

[24] Suchy, J. S., Lelito, J., Gracz, B., Zak, P. L.: China Foundry, 9, 2012, p. 184. 